Vol 10, Issue 11, 2017

\title{
A REVIEW ON PHYTOCHEMISTRY AND PHARMACOLOGICAL PROPERTIES OF MILKWEED FAMILY HERBS (ASCLEPIADACEAE)
}

\author{
PUSHPA ANANTRAO KARALE ${ }^{1 *}$, MAHESH A KARALE ${ }^{2}$
}

${ }^{1}$ Department of Pharmacology, School of Pharmacy, Swami Ramanand Teerth Marathwada University, Nanded - 431 606, Maharashtra, India. ${ }^{2}$ Department of ???, School of Life Sciences, Swami Ramanand Teerth Marathwada University, Nanded - 431 606, Maharashtra, India. Email: pushpakarale7711@gmail.com

Received: 17 July 2017, Revised and Accepted: 20 September 2017

ABSTRACT

Calotropis procera and Gymnema sylvestre are a perennial shrub and woody climber, respectively, and belonging to the family Asclepiadaceae. They are commonly known as milkweed family herbs. The Calotropis commonly have two species, i.e., C. procera and C. gigantean. All parts of plant exude white milky latex when cut. It has been widely used in traditional medicine due to its pharmacological active compounds found in all parts of plants such as bark, roots, and leaves and especially its latex which exudes from damaged or broken stem and leaves. G. sylvestre an ayurvedic herb came to be known as "destroyer of sugar" because in ancient times Ayurveda physicians observed that chewing a few leaves of $G$. sylvestre suppressed the taste of sugar. It also reported to possess antidiabetic, antioxidant, and immunomodulatory, antiulcer, and anticancer potential. The gymnemic acid is the main constituent which is responsible for number of pharmacological activities. The present review assembles the data on pharmacognostic and pharmacological potential of $C$. procera and G. sylvestre.

Keywords: Calotropis procera, Gymnema sylvestre, Milkweed, Gymnemic acid.

(C) 2017 The Authors. Published by Innovare Academic Sciences Pvt Ltd. This is an open access article under the CC BY license (http://creativecommons. org/licenses/by/4. 0/) DOI: http://dx.doi.org/10.22159/ajpcr.2017.v10i11.21215

\section{INTRODUCTION}

To make disease free healthy life medicinal plants are the nature's gift to human beings. It plays a very important role to conserve our health. India is one of the most diverse countries in the world, and the main traditional systems of medicine include Ayurveda, Unani, and Siddha [1]. From ancient times in India, different parts of medicinal plants have been used for curing various diseases. In this regard, Calotropis procera and Gymnema sylvestre are the herbs of milkweed family have reported number of pharmacological activities from antique times. The recent review represents pharmacognostic characteristics and the pharmacological potential of $C$. procera and G. sylvestre.

\section{PROCERA}

C. procera (Aiton) R.Br. is a small shrub belonging to family Asclepiadaceae, and commonly known as milkweed or giant weed. It is commonly grown in wastelands and roadside area. It is frequently known as "Rui" in Marathi, "Mudar" in Hindi, and "Sodom of apple" in English (Fig. 1). There is a number of species of Calotropis but most commonly available species include $C$. sussuela, C. acia Buch, C. gigantean (Linn), and C. procera. However, C. gigantean and C. procera are mostly found in the region of India [2]. C. procera is drought resistant, salt tolerant and it disperse seeds through wind and animals. It quickly becomes recognized as a weed along degraded roadsides and overgrazed native pastures $[3,4]$. C. procera is resident to India, Pakistan, Nepal, Afghanistan, Algeria, Iran, Iraq, Israel, Kenya, Kuwait, Nigeria, Saudi Arabia, United Arab Emirates, Yemen, and Zimbabwe [5].

The $C$. procera traditionally used in Ayurveda and other medicine systems from prehistoric time. These are useful to treatment various diseases such as diabetes, rheumatism, and inflammation. All parts of these plant used traditionally and the leaves possess anti-inflammatory and hepatoprotective potential. Table 1 summarizes the vernacular names of $C$. procera $[6,7]$.
Systemic classification of $C$. procera [8]

- Kingdom: Plantae - Plants

- Subkingdom: Tracheobionta - Vascular plants

- Super division: Spermatophyta - Seed plants

- Division: Magnoliophyta - Flowering plants

- Class: Magnoliopsida - Dicotyledons

- Subclass: Asteridae

- Order: Gentianales

- Family: Asclepiadaceae - Milkweed family

- Genus: Calotropis R.Br.

- $\quad$ Species: C. procera (Aiton).

\section{Pharmacognostic studies}

C. procera is a single or many branched, soft-wooded shrub, and irregularly a tree reaching to $6 \mathrm{~m}$ length. The monarch butterflies are the highly insects through which it pollinated. Both animals and wind disperse the seeds, flowering and fruiting takes place throughout the year. When cut all parts of the plant exude white milky latex [9]. Soils of all texture but prefer disturbed sandy soils, as well as soils with high sodium saturations, are tolerated. The characteristics plant $[10,11]$ parts of $C$. procera are depicted in Table 2. The biophysical limits for C. procera are:

- $\quad$ Altitude: Up to $1300 \mathrm{~m}$

- Mean annual rainfall: 300-400 mm

- Mean annual temperature: $20-30^{\circ} \mathrm{C}$.

Phytochemistry

C. procera has been investigated by various researchers and found to possess number of chemical constituents.

\section{Whole plant}

Phytochemistry revealed that $C$. procera has several types of compounds such as cardenolide, triterpenoids, alkaloids, resins, anthocyanins and proteolytic enzymes in latex, flavonoids, tannins, sterol, saponins, and cardiac glycosides [12]. 

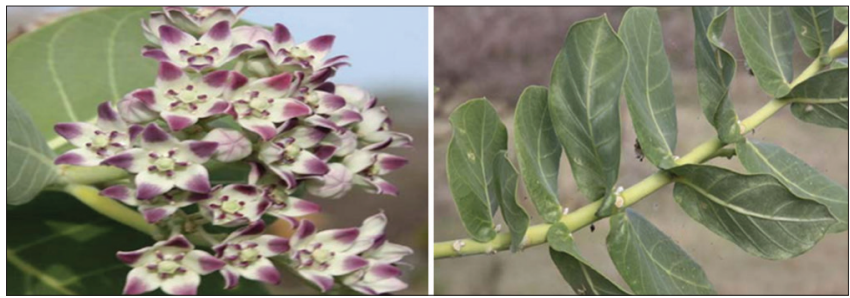

Fig. 1: Flowers and leaves of Calotropis procera

Leaves

The leaves enclose mainly the amyrin, amyrin acetate, $\beta$-sitosterol, ursolic acid, cardenolides, calotropin, and calotropagenin. The leaves of plant contain mudarine as the principal active constituent [13].

\section{Latex}

The latex of plant has calotropin, calotoxin $0.15 \%$, calactin $0.15 \%$, uscharin $0.45 \%$, trypsin, voruscharin, uzarigenin, syriogenin, and proceroside [14].

\section{Flowers}

The flavonoids, queretin-3-ratinoside, sterol, calactin, calotoxin, calotropagenin, terpenes, multiflorenol, and cyclisadol and calotropin, polysaccharides with D-arabinose, glucose, glucosamine, and L-rhamnose isolated from the flowers. Flowers also contain enzymes 3-proteinase and calotropain (protease). C. procera flowers other chemical constituents are lupeol, uscharin, proceroside, proceragenin (cardenolide), syriogenin, taraxast-20(30)-en-3-(4-methyl-3pentenoate), 3-thiazoline cardenolide, gigantin, giganteol, isogiganteol, uscharidin, uzarigenin voruscharin a-calotropeol, 3-epimoretenol, alactuceryl acetate, and a-lactuceryl isovalerate [15]

\section{Root bark}

C. procera root bark has triterpenes, a new norditerpenyl ester, named calotropterpenyl ester, and two unknown pentacyclic triterpenoids, namely, calotropursenyl acetate and calotropfriedelenyl acetate, akundarol isovalerate, mundarol isovalerate, and quercetin -3- rutinoside. The benzoyllineolone, benzoylisolineolone, calotropterpenyl ester, calotropursenyl acetate, and calotropfriedelenyl acetate also found to include in root bark (Fig. 2) [16].

\section{Traditional uses}

In Ayurveda system of medicine, the plant is known as Arka and leaves are fried in oil for medicinal purpose. Sometimes it referred to as vegetable mercury because the latex is said to have mercury like effects on the human body. The root bark was earlier used as a substitute of ipecacuanha and has a digitalis-like an effect on the heart.

The various diseases has been treated by plant and widely used in the Ayurvedic, Unani, Arabic, and Sudanese-Indian traditional system of medicine. It has been utilized as a purgative, anthelmintic, digestive, stomachic, emetic, expectorant, sedative, blood purifier, and an antidote for snake bite. The treatment of ulcers, tumors, leprosy, asthma, boils, dysentery, eczema, piles and disease of liver, abdomen, and spleen also exploited by the plant parts [17]. The plant has been traditionally used as an antifungal, analgesic, and antipyretic agent. The migraine also treated by tender leaves of the plant. It acts as an abortifacient and for the treatment of piles. It is mentioned as bitter tonic, laxative, anthelmintic, expectorant and to cure ulcer in Ayurveda. The abdomen pain is cured by applying hot leaves, while the flowers are described as tonic, appetizer, and stomachic, and to cure asthma [18]. The Ayurvedic preparations such as Dhanvantari Ghrita, Mahanarayan taila, Arka lavana, and Chitrakadi taila prepared using roots of the plant [19].

All the parts of $C$. procera have been documented to attain medicinal desirable quality in ethno botanical surveys. The leaves used for the cure of cold, cough in Uttar Pradesh and latex for toothache and
Table 1: Vernacular names of Calotropis procera

\begin{tabular}{ll}
\hline Language & Common name \\
\hline English & Calotropis, Rooster tree, Mudar plant \\
Marathi & Rui, Mandara \\
Hindi & Aaka, Aanaka \\
Urdu & Madar, Aak \\
Sanskrit & Arka, Alaka, Ravi \\
Gujarati & Akado \\
Arabic & Oshar \\
Kannada & Ekka, Ekkada gida \\
Telugu & Jilledu \\
Panjabi & Ak \\
Tamil & Vellerukku \\
Bengali & Akanda, Akone \\
Malayalam & Erikku \\
\hline
\end{tabular}

Table 2: Characteristics of plant parts of Calotropis procera

\begin{tabular}{|c|c|c|}
\hline S.No. & Plant parts & Description \\
\hline 1 & Bark and branches & $\begin{array}{l}\text { Thick, rough, corky and } \\
\text { yellow-brown color; twigs are } \\
\text { green and fleshy }\end{array}$ \\
\hline 2 & Leaves & $\begin{array}{l}\text { Opposite-decussate, simple, ovate } \\
\text { to obovate, quite large about } \\
30 \mathrm{~cm} \times 25 \mathrm{~cm}\end{array}$ \\
\hline 3 & Flowers & $\begin{array}{l}\text { White at the base and purple } \\
\text { at the tips and } 5 \text { purple tipped } \\
\text { stamens, } 5 \text { thick ovate petals }\end{array}$ \\
\hline 4 & Fruits & $\begin{array}{l}\text { Green, spongy ovoid, up to } 15 \mathrm{~cm} \\
\text { long by } 10 \mathrm{~cm} \text { wide }\end{array}$ \\
\hline 5 & Inflorescence & $\begin{array}{l}\text { Arise from the base of the leaves } \\
\text { in pedunculate cymes of } 3-20\end{array}$ \\
\hline 6 & Root bark & $\begin{array}{l}\text { Cracked, yellowish gray outside } \\
\text { and yellowish white inside. Dried } \\
\text { bark is bitter to taste }\end{array}$ \\
\hline 7 & Roots & $\begin{array}{l}\text { Grayish white in color and exhibit } \\
\text { sap exudations at the places } \\
\text { where bark has been cut }\end{array}$ \\
\hline 8 & Corolla & $\begin{array}{l}\text { Regular, gamopetalous, pale } \\
\text { rose-purple or lilac, with a } \\
\text { short tube and five broad ovate } \\
\text { spreading lobes }\end{array}$ \\
\hline
\end{tabular}

scorpion bite. The treatment of dropsy, rheumatism, leprosy, and taeniasis using latex carried out in districts of Madhya Pradesh. The latex used for application on wounds in rural areas of Jammu was reported [16].

\section{Pharmacological activities}

Different parts of $C$. procera have been used for their biological activities since anciently, and some of them have an experimental opinion for their acceptance. Apart from their use in folk medicine, there are several reports on the biological activities and pharmacological actions of $C$. procera based on modern scientific investigation.

\section{Antimicrobial activity}

C. procera latex was evaluated for antimicrobial activity against Escherichia coli, Streptococcus pneumonia, Bacilluscereus, Staphylococcus saprophyticus, and Staphylococcus aureus using disc diffusion method. Plant latex gives activity against most of the microorganisms [20]. Antimicrobial activity of solvent extracts and flavonoids of $C$. procera were reported using agar well-diffusion method. The flavonoids fraction of methanolic extract confirms the highest antimicrobial activity and quercetin-3-0-rutinoside have superior activity over the rest of flavonoids. The Gram-positive bacteria were more vulnerable than the Gram-negative, and the yeast species were more susceptible than the filamentous fungi [21]. 


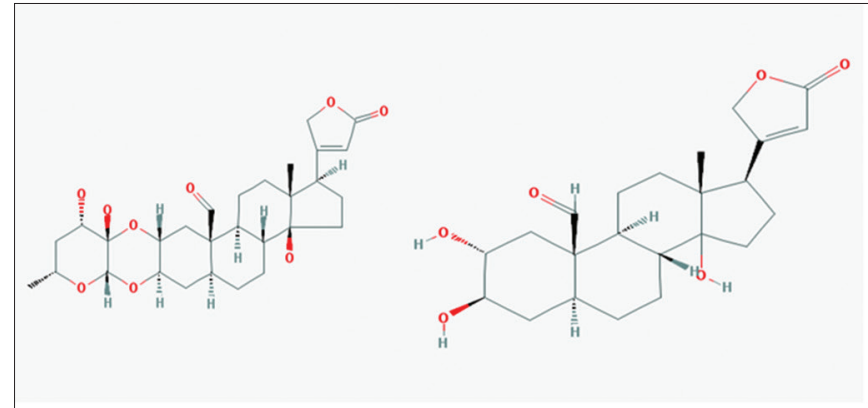

(a) Calotropin (b) Calotropagenin

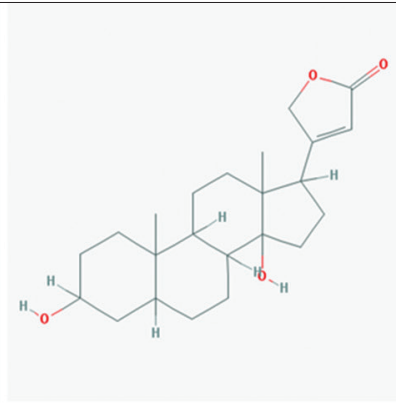

(c) Uzarigenin

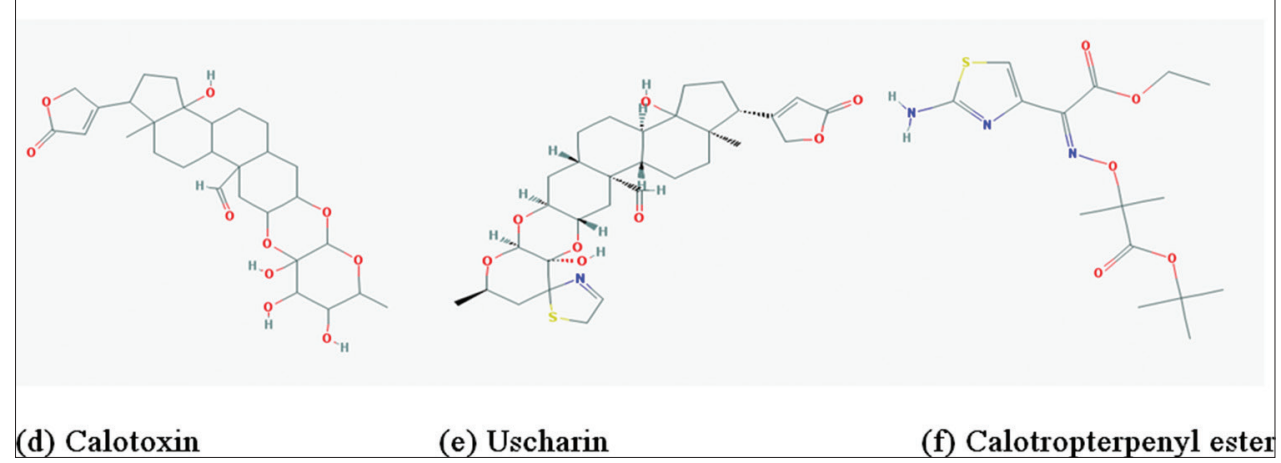

Fig. 2: (a) Calotropin (b) Calotropagenin (c) Uzarigenin (d) Calotoxin (e) Uscharin (f) Calotropterpenyl ester

\section{Insecticidal activity}

The larvicidal potential against Musca domestica was reported for ethanol extract of $C$. procera leaves by dipping method for $48 \mathrm{hrs}$. The leaf extract of $C$. procera was originated to be more active in terms of insecticidal potential. The data point out that the leaf extracts of these plants may be utilized as safer and economic alternatives to the synthetic insecticides [22].

\section{Antibacterial activity}

The aqueous and ethanolic extracts of root and leaves of $C$. procera evaluated for antibacterial potential using disc method. The ethanolic extract of leaves and roots was reported to possess higher antibacterial potential than the aqueous extract [23]. The antibacterial effect of extracts of leaf was reported and determined using agar well diffusion method, and minimum inhibitory concentration was determined using serial dilution method. The study revealed the significant antibacterial activity of all extracts [24].

\section{Antioxidant activity}

Methanolic extract of leaves, flowers, and root investigated to has antioxidant activity by radical (1,1-diphenyl-2-picrylhydrazyl [DPPH]) scavenging, reducing power; ferric reducing ability of plasma assay and metal chelating activity assay. The higher antioxidant potential reported for leaves of $C$. procera with inhibitory concentration $50 \%$ values of $0.21 \mu \mathrm{g} / \mathrm{ml}$ for DPPH scavenging, $0.98 \mathrm{mg} / \mathrm{ml}$ for metal chelating [25]. The plant extract showed promising source of antioxidant due to the presence of phenolics and tannins [26].

\section{Analgesic activity}

The methanolic extract of $C$. procera exhibited a dose-dependent analgesic action in acetic acid writhing method. C. procera extract confirmed outstanding response in comparison to aspirin [27]. Ethanolic extract of the leaf of $C$. procera confirms the prominent analgesic potential and investigated for its analgesic activity using acetic acid-induced writhing and tail flick tests in mice [28].

\section{Anti-inflammatory activity}

The anti-inflammatory effect of methanolic extracts of $C$. procera was tested for formalin-induced paw edema in white albino mice and exhibited a dose-dependent anti-inflammatory potential [27]. Ethanolic extract of the leaf of $C$. procera was reported anti-inflammatory potential using formalin-induced paw lick, carrageenan-induced paw edema in Wistar rats. The extract showed inhibition of formation of paw edema significantly higher than of indomethacin [28]. The dry latex of C. procera was demonstrated anti-inflammatory activity using acute and chronic model of inflammation. Inhibition of fluid exudation, possibly due to its effect on vascular permeability was performed by DL significantly [29]. The potent anti-inflammatory activity was reported for methanolic extract of plant $C$. procera against acute and chronic model in albino Wistar rats. The methanolic extract of roots illustrated very close activity to the inhibitory effect of diclofenac sodium [30].

\section{Hepatoprotective activity}

Hepatoprotective activity of ethanolic extract of flowers of $C$. procera was illustrated, and it may be recognized to the quercetin related flavonoids present in flower [31]. Ethanolic and water extract of flowers also reported their hepatoprotective activity. The coadministration of antituberculosis drugs with $\mathrm{CP}$ has reduced levels of alanine amino transferase, aspartate amino transferase, and bilirubin within the normal range [32].

\section{Antidiabetic activity}

The petroleum ether, methanol and aqueous extracts of leaves of C. procera at a dose of $250 \mathrm{mg} / \mathrm{kg}$ were accounted for its antihyperglycemic potential. The investigation established pharmacological evidence to support the folklore claim that it is an antidiabetic agent [33]. The antidiabetic activity of hydroalcoholic extract of the leaves was investigated and illustrated the inhibition of level of blood glucose throughout the evaluation period [34].

\section{Antiulcer activity}

The stem bark of $C$. procera was studied for gastro-mucosal protective effect using aspirin and ethanol model in albino rats. A significant 
gastro-mucosal protective effect showed by chloroform extract at $400 \mathrm{mg} / \mathrm{kg}$ [35]. The antiulcerogenic potential of an extract of leaves and root was investigated and accounted a dose-dependent reduction of lesion formation [36].

\section{Anticancer activity}

The root extracts of $C$. procera were reported antitumor potential against Hep2 cancer cells. Tetrazolium bromide colorimetry was used for cellular proliferation activities [37]. A complete protection against hepatocarcinogenesis showed by dried latex treatment of mice.

\section{G. SYLVESTRE}

G. sylvestre is one of the powerful medicinal plants used from prehistoric times. It is perennial, woody climber spread through in dry forest up to height of $600 \mathrm{~m}$ [38]. It is commonly known as Gurmar in Hindi. The Greek words "Gymnos" means naked and "nema" means thread while the specific description "sylvestre" is of Latin origin means "of the forest" [39]. G. sylvestre is generally disseminated in India, Malaysia, Sri Lanka, Indonesia, Japan, Vietnam, tropical Africa, and South Western region of the people's republic of China. It is also found in Banda, Konkan, Western Ghats, and Deccan extending to the parts of Western and Northern India (Fig. 3).

The genus Gymnema consists of 40 species distributed from Western Africa to Australia. Gymnema acuminatum (Roxb.) wall, Gymnema aurantiacum, Gymnema balsamicum, Gymnema elegans $\mathrm{W}$ and $\mathrm{A}$, Gymnema lactiferum, Gymnema latifolium, Gymnema montanum Hook. F., G. sylvestre R.Br., Gymnema tingens W and A, Gymnema inodorum, Gymnema yunnanense, and Gymnema spartum are some of the important species of Gymnema $[40,41]$. Ayurvedic and Homeopathic system of medicine used $G$. sylvestre as a potent antidiabetic herb. It also reported to be a bitter, astringent, diuretic, laxative, stomachic, liver tonic, stimulant, expectorant, and antipyretic agent. The vernacular names of G. sylvestre as depicted in Table 3.

\section{Taxonomical classification of $\boldsymbol{G}$. sylvestre \\ - Kingdom: Plantae \\ - Subkingdom: Tracheobionta \\ - Super division: Spermatophyta \\ - Division: Magnoliophyta \\ - Class: Magnoliopsida \\ - Subclass: Asteridae \\ - Order: Gentianales \\ - Family: Asclepiadaceae \\ - Genus: Gymnema \\ - Species: G. sylvestre.}

\section{Pharmacognostic studies}

The plant is more or less juvenile woody climber running over the high trees. G. sylvestre is native to the tropical forests of Southern and Central India and grown in the plains of coast in jungles at an altitude of 300-700 $\mathrm{m}[44,45]$. The pharmacognostic characteristic of the G. sylvestre as presented in Table 4. The Gymnema species are diploid with a chromosome number of $2 n=22[46,47]$.

\section{Phytochemistry}

A number of phytochemical constituents have been reported by several researchers. Plant comprises two resins one soluble in alcohol, saponins, gymnemic acid, stigmasterol, quercitol and amino acid derivatives betaine, choline, and trimethylamine [48]. The leaves of G. sylvestre contains resins, albumin, chlorophyll, carbohydrates, tartaric acid, formic acid, butyric acid, anthraquinone derivatives, inositol alkaloids, organic acid (5.5\%), paraben, calcium oxalate (7.3\%), lignin $(4.8 \%)$, and $22 \%$ of cellulose [49]. The leaves also enclose triterpene classes of oleanane saponins such as gymnemic acids, gymnemasaponins, and dammarane saponins such as gymnemasides and terpenoids as 6-octen1-ol, 3,7-dimethyl, isophytol, squalene, nerolidol, and $\beta$-amyrin [50,51].
Leaves of $G$. sylvestre have acidic glycosides and anthraquinones and their derivatives [50]. Gymnemic acids A2 and A3 possessed both glucuronic acid and galactose in their molecular structures while glucuronic acid was found to be the only moiety in gymnemic acid A1 [52]. Further, a gymnemic acids series (gymnemic acid I, II, III, IV, V, VI, and VII) were isolated and characterized from the hot water extract of dry leaves of $G$. sylvestre [53,54]. An important 35 amino acid peptide gurmarin having a molecular weight of 4209 was isolated from G. sylvestre (Fig. 4) [55].

\section{Traditional uses}

Sushruta describes $G$. sylvestre as destroyer of sugar and other urinary diseases and these activities due to $G$. sylvestre neutralizing excess sugar in body [56]. Leaves of gurmar used traditionally for treatment of diabetes, piles and insect bites are treated by root bark [57]. The plant is useful in treatment of dyspepsia, constipation, jaundice, hemorrhoids, renal and vesical calculi, cardiopathy, asthma, bronchitis, amenorrhea, conjunctivitis, leukoderma, and Parkinsonism [58]. In Siddha and Unani systems of medicine, the Gymnema leaves are used as an ingredient of different antidiabetic formulations [59].

G. sylvestre is considered an alexipharmic, anodyne, anthelmintic, antipyretic astringent, bitter, cardiotonic, digestive, diuretic, laxative, stimulant, stomachic, and uterine tonic and is used to treat amenorrhea, asthma, bronchitis, conjunctivitis, constipation, cough dyspepsia, hemorrhoids, hepatosplenomegaly, intermittent fever, jaundice, and leukoderma according to Indian systems of medicine. The plant leaves are useful to remove inflammation. The bark from the plant roots is useful as an emetic, expectorant, and analgesic for body ache and juice from the root has been acclaimed as a useful treatment for snakebite by Bhav Prakash Nighantu [60,61]. The various formulations used for the treatment of diabetes as predicted in Table 5 [62].

\section{Pharmacological activities}

G. sylvestre is one of the essential medicinal plants used in ayurvedic system of medicine for the treatment of diverse diseases (Fig. 5) and is well known for their sugar suppressing activity.

Table 3: Vernacular names of Gymnema sylvestre [42,43]

\begin{tabular}{ll}
\hline Language & Common name \\
\hline Hindi & Gudmar \\
Kannada & Kadhasige \\
Malayalam & Chakkarakolli, Madhunashini \\
Tamil & Sirukurunja/Sakkaraikkolli \\
Sanskrit & Measuring, jaboli \\
Telugu & Podapatri \\
English & Periploca of the wood \\
Marathi & Kavali, Kalikardori, Vakundi \\
Gujarati & Dhuleti, Mardashingi \\
\hline
\end{tabular}

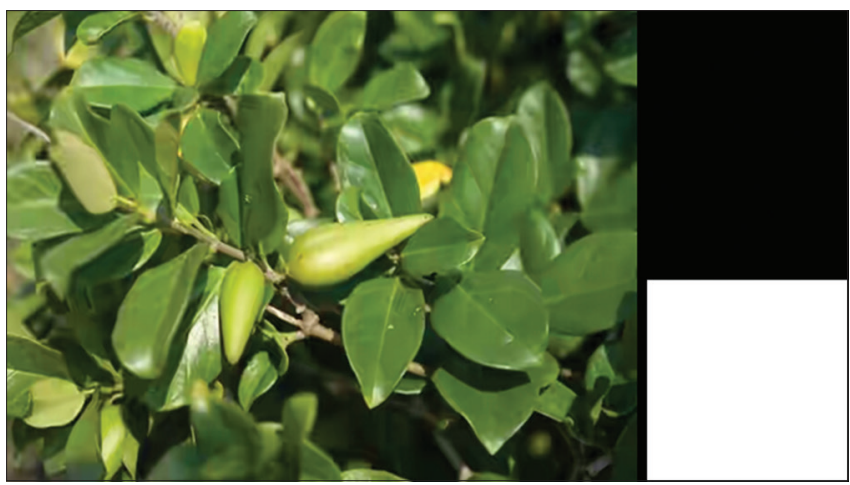

Fig. 3: Leaves, flowers, and fruit of Gymnema sylvestre 


\section{Antidiabetic activity}

The gymnemic acid the main constituent encloses different saponins and delays the glucose absorption in the blood due to the similarity with the atomic arrangement of the glucose. The leaf extract administered to patient stimulate the pancreas and increase release of insulin [63]. The extract of $G$. sylvestre encourages release of insulin from $\beta$-cells and from islets in the absence of any other stimulus [64]. Clinical study of G. sylvestre revealed antidiabetic potential in Type II diabetic patient for blood glucose level. G. sylvestre capsule reduced $37 \%$ glucose, $5 \%$

Table 4: Morphological characteristics of plant parts of Gymnema sylvestre

\begin{tabular}{|c|c|c|}
\hline S.No. & Plant parts & Description \\
\hline 1 & Stem & $\begin{array}{l}\text { Cylindrical, hard, twining, branched; } \\
\text { internodes terete; rooting at nodes }\end{array}$ \\
\hline 2 & Leaves & $\begin{array}{l}\text { Opposite, elliptic or ovate, } \\
1.0-9.5 \mathrm{~cm} \times 0.5-5.5 \mathrm{~cm} \text {, acute at apex, } \\
\text { base rounded, ciliate along margins, } \\
\text { smooth above, densely velvety } \\
\text { pubescent beneath, especially on the } \\
\text { nerves }\end{array}$ \\
\hline 3 & Flowers & $\begin{array}{l}\text { Small, yellow, in axillary and lateral } \\
\text { umbellate cymes } \\
\text { Flowering: August-March }\end{array}$ \\
\hline 4 & Calyx & 5-lobed, ovate, obtuse, ciliated \\
\hline 5 & Corolla & $\begin{array}{l}\text { Campanulate, yellow, } 5 \text {-lobed; lobes } \\
\text { ovate-deltoid, spreading and glabrous, } \\
\text { united at base }\end{array}$ \\
\hline 6 & Fruits & $\begin{array}{l}2 \text { or 1, dark green smooth follicular } \\
\text { mericarps } \\
\text { Fruiting: from October onward }\end{array}$ \\
\hline 7 & Seeds & $\begin{array}{l}\text { Ovate, margined, ending in a silky coma, } \\
\text { cotyledons elliptic, radicle cylindric }\end{array}$ \\
\hline
\end{tabular}

triglycerides level, 13\% cholesterol, and 19\% low-density lipoproteins (LDL) level in diabetic individuals [65].

Glucoscare herbal tea (GCT) consists of two plants, namely, the G. sylvestre and Camellia sinensis assessed for antidiabetic activity. The complimentary effects on $\mathrm{HbA1c}$ and fasting blood sugar in patients with uncontrolled Type 2 diabetes mellitus after 12 weeks showed by GCT [66]. The study revealed that $G$. sylvestre leaves aqueous extracts augmented $\beta$-cell expansion and potentiated glucose-evoked $\mathrm{Ca}^{2+}$ regulated insulin secretion [67].

\section{Antibacterial activity}

The ethanolic extract of leaves illustrated high degree of antibacterial activity [68]. The antimicrobial activity against Bacillus pumilus, Bacillus subtilis, Pseudomonas aeruginosa, and S. aureus demonstrated by ethanolic extract of $G$. sylvestre leaves [69]. Aqueous and methanolic leaf extracts were studied for their antimicrobial efficacy, the methanolic extract of the leaves demonstrated activity against all four tested microorganisms while aqueous leaf extracts found to be non-effective [70]. The aqueous and methanol leaf extract showed significant antibacterial activity [71].

\section{Antiobesity activity}

G. sylvestre possesses lipid-lowering potential due to inhibition of pancreatic lipase activity. The study clear that decoction of leaves is useful in obesity [72]. A decrease in food and water intake along with a body weight reduction of $57.2 \pm 6.4$ and $75.5 \pm 6.3 \mathrm{~g}$ during 1 and 2 weeks, respectively, observed in Otsuka Long-Evans Tokushima fatty rats [73]. The narrative combination has resulted in significant body weight and fat loss in obese adults [74].

\section{Hypolipidemic activity}

Gymnemate extracted from $G$. sylvestre extract found to decrease the total cholesterol by about $1 / 3$, and the LDL and very LDL cholesterol has

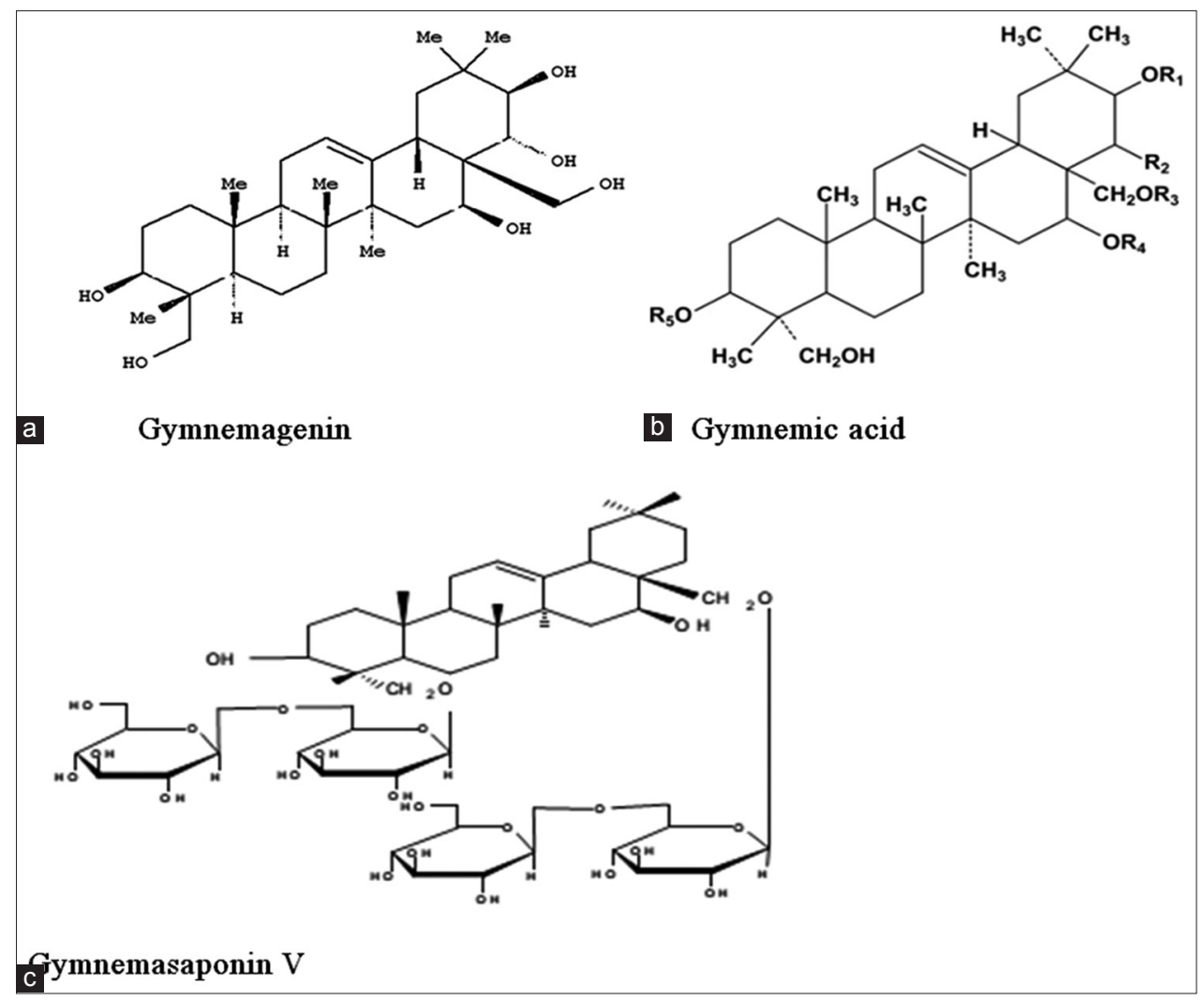

Fig. 4: (a) Gymnemagenin. (b) Gymnemic acid. (c) Gymnemasaponin V 
decreased by about half [75]. The ethanolic extract study illustrated that decrease in the circulating cholesterol concentrations in spontaneously hypersensitive rats [76]. Gymnemic acids have found to increase the fecal excretion of neutral steroids and bile acids especially those of cholesterol and cholic acid derived bile acids [77]. The aqueous leaf extracts of $G$. sylvestre significantly diminished cholesterol and serum triglycerides and the treated rat's serum high-density lipoprotein cholesterol level were increased [78]

\section{Anticancer activity}

The biosynthesized silver nanoparticles and gold nanoparticles of $G$. sylvestre leaf extract exhibited substantial in vitro cytotoxic effects against Hep2 cells. Among the two nanoparticles synthesized, silver showed better cytotoxic effects in cancer cells than gold nanoparticles [79]. The gymnemagenol at $50 \mu \mathrm{g} / \mathrm{ml}$ showed a good cytotoxic activity (63\%) in HeLa cells at $48 \mathrm{hrs}$. [80]. G. sylvestre extract reported a significant reduction in tumor incidence, tumor burden and cumulative number of papillomas along with a significant increase in average latent period [81].

\section{Antioxidant activity}

The ethanolic extract of $G$. sylvestre reported antioxidant activity by inhibiting DPPH; it might be due to the presence of saponins, flavonoids, phenols, and alkaloids [82]. The antioxidant activity of G. sylvestre leaves showed concentration-dependent response and it varied from $3.92 \%$ to $72.22 \%$ for $7.81-1000 \mu \mathrm{g} / \mathrm{ml}$, respectively [83].

\section{Immunomodulatory activity}

The study designated that methanolic extract of G. sylvestre exhibited significant immunosuppressive activity by inhibiting the increase in

Table 5: Antidiabetic traditional formulations of Gymnema sylvestre

\begin{tabular}{|c|c|c|}
\hline S.No. & Formulation name & Ingredients \\
\hline 1 & Diabet guard & Gymnema sylvestre extract \\
\hline 2 & Alfasilin & $\begin{array}{l}\text { Gymnema sylvestre extract } \\
\text { and banana extract }\end{array}$ \\
\hline 3 & Ultradia & $\begin{array}{l}\text { Gymnema sylvestre extract } \\
\text { and banana extract }\end{array}$ \\
\hline 4 & Diabohills & Gymnema sylvestre extract \\
\hline 5 & Hyponidd & Gymnema sylvestre extract \\
\hline
\end{tabular}

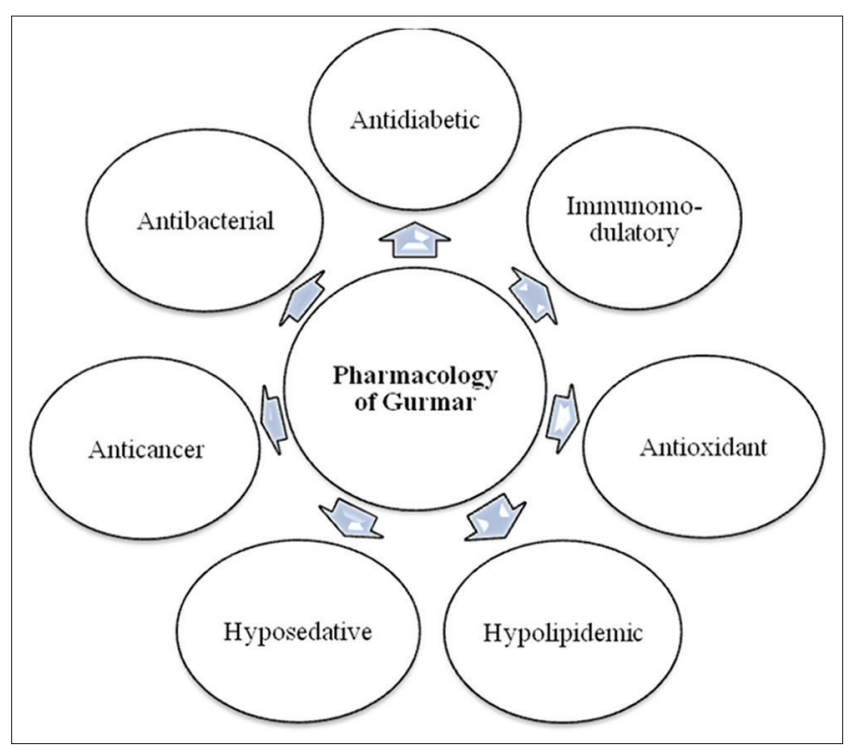

Fig. 5: Pharmacological activities of Gymnema sylvestre
CD3 and CD19 lymphocytes and cytokines, interleukin 2, interferon- $\gamma$, and IL-4 [84]. G. sylvestre aqueous leaf extracts showed remarkable immunostimulatory activity on human neutrophils under in vitro conditions [85].

\section{Antiulcer activity}

Ethanolic leaf extract reported protective effect in the experimentally induced ulcerative colitis by acetic acid in Wister rats. Long-term administration of alcoholic leaf extracts did not show any influence on hematological and blood chemical parameters. 1\% in diet/52 weeks showed no observable toxic effect in rats [86]. Gymnemic acid appraised antiulcerogenic potential by the inhibition of prostaglandin synthesis and generation of ulcer [87].

\section{CONCLUSION}

The WHO report has estimated that in developing countries more than $80 \%$ of the population depends on herbal medicines for their basic healthcare needs [88]. Synthetic medicines acquire resistance day by day for the many microorganisms and therefore it desirable to move toward herbal medicines and their combinations. Plant origin drugs have established much attention of the world for their efficacy and whispered to be safe for human use. Herbal medicine has good scope in the field of new drug therapy as well as nutraceuticals [89]. G. sylvestre is a multipurpose potential medicinal plant having a high market potential worldwide. G. sylvestre has an important place with its diverse ethnobotanical, traditional uses and economic uses in different systems of medicine not only in India but also throughout the world. It exhibits enormous hypoglycemic activity along with hypolipidemic and antioxidant property. G. sylvestre has clinical evidences to treat diabetes and tradition antidiabetic formulation showed their hypoglycemic potential by any one or all the mechanism of increase secretion of insulin; promotes regeneration of islet cells and increase utilization of glucose. As the synthetic agents act by only one pathway but the herbal remedies have to show the various pathways due to their phytochemicals to treat diseases. The $C$. procera contains various secondary metabolites which are responsible for the pharmacological potential. This review will be beneficial to the scientists and researchers to further investigation and development of the new drug from the relevant studies.

\section{REFERENCES}

1. Vasant L. Ayurveda: The Science of Self-Healing. $1^{\text {st }}$ ed. Delhi: Motilal Banarsidass; 1994. p. 18.

2. Lorenzi H, Matos FJ. Plantas Medicinais no Brasil: Native Seexoticas. São Paulo: Instituto Plantarum; 2002.

3. Orwa B, Tayeb AE, Sulleiman YR. Calotropis procera: Feed potential for arid zones. Vet Rec 2009;131(6):132.

4. Magalhães HI, Ferreira PM, Moura ES, Torres MR, Alves AP, Pessoa OD, et al. In vitro and in vivo antiproliferative activity of Calotropis procera stem extracts. An Acad Bras Cienc 2010;82(2):407-16.

5. Parsons WT, Cuthbertson EG. Noxious Weeds of Australia. Collingwood: CSIRO Publishing; 2001.

6. Sharma AK, Kharb R, Kaur R. Pharmacognostical aspects of Calotropis procera (Ait.) R. Br. Int J Pharm Bio Sci 2011;2:480-8.

7. Gupta S, Gupta B, Kapoor K, Sharma P. Ethnopharmacological potential of Calotropis procera: An overview. Int Res J Pharm 2012;3:19-22.

8. Khairnar AK, Bhamare SR, Bhamare HP. Calotropis procera: An ethno-pharmacological update. ARPB 2012;2:142-56.

9. Basu A, Chaudhary AK. Preliminary studies on the anti-inflammatory and analgesic activities of Rakta arka root extract. J Ethnopharm 1997;31:319-24.

10. Nadkarni KM. The Indian Materia Medica I. Bombay: Popular Prakashan; 2000.

11. Trease GE, Evans WC. Phenols and phenolic glycosides. In: Textbook of Pharmacognosy. $12^{\text {th }}$ ed. London: Balliese, Tindall and Co. Publishers; 1989. p. 343-83.

12. Erdman MD. Nutrient and cardenolide composition of unextracted and solvent-extracted Calotropis procera. J Agric Food Chem 1983;31(3):509-13.

13. Khan AQ, Malik A. A steroid from Calotropis procera. Phytochemestry 1989;28:2859-61. 
14. Rastogi RP, Mehrotra BN. Compendium of Indian Medicinal Plants. New Delhi: Central Drug Research Institute, Lucknow and Publication and Information Directorate; 1993. p. 71-2.

15. Poonam PG. A review on varieties of Arka-Calotropis procera (Aiton) dryand. and Calotropis gigantean Dryand. Glob J Res Med Plants Indig Med 2013;2:392-400.

16. Quazi S, Mathur K, Arora S. Calotropis procera: An overview of its phyto-chemistry and pharmacology. Indian J Drugs 2013;1:63-9.

17. Kumar MA, Yadav A, Rao MM. Ayurvedic uses and pharmacological activities of Calotropis procera Linn. Asian J Tradit Med 2011;6:45-53.

18. Kirtikar KR, Basu BD. An Indian Medicinal Plants. $2^{\text {nd }}$ ed. Dehra Dun: Bishen Singh Mahendra Pal Singh; 1984. p. 2422-23.

19. Government of India, Ministry of Health and Family Planning. The Ayurvedic Formulary of India. $1^{\text {st }}$ ed. New Delhi: Govt. of India, Ministry of Health and Family Planning; 1978.

20. Maithani NB, Alam J. Ethanobotanically importance and investigation of phytochemical and antimicrobial potential of Calotropis procera. Herbs 2013;1:34-41.

21. Nenaah G. Antimicrobial activity of Calotropis procera Ait. (Asclepiadaceae) and isolation of four flavonoid glycosides as the active constituents. World J Microbiol Biotechnol 2013;29(7):1255-62.

22. Begum N, Sharma B, Pandey RS. Evaluation of insecticidal efficacy of Calotropis procera and Annona squamosa ethanol extracts against Musca domestica. J Biofertilizers Biopestic 2010;1:1-6.

23. Mako GA, Memon AH, Mughal UR, Pirzado AJ, Bhatti SA. Antibacterial effects of leaves and root extract of Calotropis procera Linn. Pak J Agric Eng Vet Sci 2012;28:141-9.

24. Shetty VG, Patil MG, Dound AS. Evaluation of phytochemical and antibacterial properties of Calotropis procera (Ait) R. Br. Leaves. Int J Pharm Pharm Sci 2015;7(4):316-9.

25. Patel HV, Patel JD, Patel B. Comparative efficacy of phytochemical analysis and antioxidant activity of methanolic extract of Calotropis gigantea and Calotropis procera. Int J Bio Pharm Res 2014;5:107-13.

26. Banerjee S, Kaushik S, Tomar RS. Effect of different solvents on antioxidant activity of leaf extracts of Calotropis procera and Azadirachta indica. Asian J Pharm Clin Res 2017;10(1):268-72.

27. Gyawali R, Bhattarai P, Dhakal S, Jha B, Sharma SK, Koirala P, et al. Analgesic and anti-inflammatory properties of Salix alba Linn and Calotropis procera (Aiton) Dryand. Int J Pharm Bio Arch 2013;4:873-7.

28. Saba AB, Oguntoke PC, Oridupa OA. Anti-inflammatory and analgesic activities of ethanolic leaf extract of Calotropis procera. Afr J Biomed Res 2011;14:203-8.

29. Kumar VL, Sangraula H, Dewan S. Evaluation of anti-inflammatory activity of latex of Calotropis procera in different models of inflammation. Inflammopharmacol 2002;9:257-64.

30. Babu AR, Karki SS. Antiinflammatory activity of various extracts of roots of Calotropis procera against different inflammation models. Int J Pharm Pharm Sci 2011;3:191-4

31. Qureshi AA, Prakash T, Patil T, Viswanath Swamy AH, Gouda AV, Prabhu K, et al. Hepatoprotective and antioxidant activities of flowers of Calotropis procera (Ait) $\mathrm{R}$. Br. in $\mathrm{CCl} 4$ induced hepatic damage. Indian J Exp Biol 2007;45(3):304-10.

32. Kamil N, Imran-Ul-Haque HS. Hepatoprotective effect of Calotropis procera in isoniazid and rifampicin induced hepatotoxicity. Pharmacogn J 2014;6:9-15

33. Bhaskar VH, Singh SA. Evaluation of anti-hperglycemic activity of extracts of Calotropis procera (Ait.) $\mathrm{R}$. Br on streptozotocin induced diabetic rats. Glob J Pharmacol 2009;3:95-8.

34. Netoa MC, Carlos FB, Thijana VN, Caldasa GF, Araujob AV, Costa-Silvac JH, et al. Evaluation of anti-hyperglycaemic activity of Calotropis procera leaves extract on streptozotocin-induced diabetes in Wistar rats. Rev Bras Farmacogn 2013;23:913-9.

35. Tour NS, Talele GS. Gastric antiulcer and anti-inflammatory activities of Calotropis procera stems bark. Rev Bras Farmacogn Braz J Pharmacogn 2011;21:1118-26.

36. Badombena-Wanta DB, Metowogo K, Tettegah M, Lawson-Evi P, Eklu GK, Aklikokou AK, et al. Comparative anti-ulcers effect of hydroalcoholic extract of leaves and root of Calotropis procera Ait. Res J Pharm Bio Chem Sci 2013:4:1205-12.

37. Mathur R, Gupta SK, Mathur SR, Velpandian T. Anti-tumor studies with extracts of Calotropis procera (Ait.) R.Br. root employing Hep2 cells and their possible mechanism of action. Indian J Exp Biol 2009;47(5):343-8.

38. Giovanni DF, Valeria R, Cinzia DM, Antonio P, Armando Z. Gymnema sylvestre R. Br., an Indian medicinal herb: Traditional uses, chemical composition, and biological activity. Curr Pharm Biotechnol 2015;16:506-16.
39. Sabitha RA, Nagamani V, Patnaik S, Saidulu B. Gymnema sylvestre: An important anti diabetic plant of India: A review. Plant Sci Feed 2012;2:174-9.

40. Keshavamurthy KR, Yoganarasimhan SN. Flora of Coorg-Karnataka. Bangalore: Vimsat Publishers; 1990. p. 282.

41. Grover JK, Yadav S, Vats V. Medicinal plants of India with anti-diabetic potential. J Ethnopharmacol 2002;81(1):81-100.

42. Subramaniyan V, Srinivasan P. Gymnema sylvestre-a key for diabetes management-a review. Biomed Res 2014;1(1):1-10.

43. Anonymous. The Wealth of India: Raw Materials. Vol. IV. New Delhi: Publication and Information Directorate, CSIR; 1956. p. 276-7.

44. Gamble JS. Asclepiadaceae. In: Flora of the Presidency Madras. Vol. 2. Calcutta: Printed Under of the Authority of the Government of India; 1956. p. 589-90.

45. Mathew KM, Rani N. Asclepiadaceae. In: The Flora of the Tamil Nadu Carnatic Part Two. Madras, India: Rapinat Herbarium, Diocesan Press; 1983. p. $945-7$

46. Caius JF, Mhaskar KS, Blatter E. ???. Vol. 3. Dehardun: Bishen Singh and Mahaendra Pal Singh Publ.; 1975. p. 1624.

47. Sredeevi P, Namboodiri AN. IOPB chromosome numbers reports, LVI. Taxon 1977;26:257-74

48. Kapoor LD. Handbook of Ayurvedic Medicinal Plants. Boca Raton, FL: CRC Press, Inc.; 1990. p. 200-1.

49. Manni PE, Sinsheimer JE. Constituents from Gymnema sylvestre Leaves. J Pharm Sci 1965;54(10):1541-4

50. Dateo GP Jr, Long L Jr. Gymnemic acid, the antisaccharine principle of Gymnema sylvestre. Studies on the isolation and heterogeneity of gymnemic acid A1. J Agric Food Chem 1973;21(5):899-903.

51. Srinivasan K, Kumaravel S. Unraveling the potential phytochemical compounds of Gymnema Sylvestre through Gc-Ms study. Int J Pharm Pharm Sci 2016;8(1):450-3.

52. Chakravarti D, Debnath NB. Isolation of gymnemagenin the sapogenin from Gymnema sylvestre R.Br. (Asclepiadaceae). J Inst Chem 1981;53:155-8.

53. Yoshikawa K, Amimoto K, Arihara S, Matsuura K. Structure studies of new anti-sweet constituents from Gymnema sylvestre. Tetrahedron Lett 1989;30(9):1103-6.

54. Yoshikawa K, Amimoto K, Arihara S, Matsuura K. Gymnemic acid V, VI and VII from gur-ma, the leaves of Gymnema sylvestre R.Br. Chem Pharm Bull 1989;37(3):852-4.

55. Imoto T, Miyasaka A, Ishima R, Akasaka K. A novel peptide isolated from the leaves of Gymnema sylvestre-I. Characterization and its suppressive effect on the neural responses to sweet taste stimuli in the rat. Comp Biochem Physiol A Comp Physiol 1991;100(2):309-14.

56. Nadkarni KM. Gymnema sylvestre: Indian Materia Medica with Ayurvedic Unani. Vol. I. Bombay: Popular Prakashan; 1986. p. 596-9.

57. Kirtikar KR, Basu BD. Indian Medicinal Plants. Vol. 3. Delhi: Periodicals Experts; 1975. p. 1625

58. Chopra RN, Nayar SL, Chopra IC. Glossary of Indian Medicinal Plants. New Delhi: CSIR; 1956, p. 1624-7.

59. Anonymous. Gurmar Buti: Standardization of Single Drugs of Unani Medicine: Part III. New Delhi: Central Council for Research in Unani Medicine, Ministry of Health \& Family Welfare, Govt. of India; 1997. p. $115-23$.

60. Sastry BS. Gymnema sylvestre. Varanasi, India: Bhav Prakash Nighantu, Chaukhambha; 1994. p. 443-4.

61. Sastry JL. Gymnema sylvestre R.Br. Dravyaguna Vijnana. Vol. 2. Varanasi, India: Chaukhamba Orientalia; 2005. p. 844-5.

62. Available from: http://www.diabetes-herbs.com, http://www.bioporex. com.

63. Kanetkar PV, Laddha KS, Kamat MY. Gymnemic acids: A molecular perspective of its action on carbohydrate metabolism, poster presented at the $16^{\text {th }}$ ICFOST meet organized. Mysore, India: CFTRI, DFRL; 2004.

64. Persaud SJ, Liu B, Henry AA. Characterisation of the insulinotropic activity of an aqueous extract of Gymnema sylvestre in mouse-cells and human Islets of Langerhans. Int J Exp Clin Cell Physiol Biochem Pharmacol 2009;23:1-3.

65. Li Y, Zheng M, Zhai X, Huang Y, Khalid A, Malik A, et al. Effect ofGymnema sylvestre, citrullus colocynthis and Artemisia absinthium on blood glucose and lipid profile in diabetic human. Acta Pol Pharm 2015;72(5):981-5

66. Nani D, Suhaila MY, Faridah MZ, Zahiruddin WM. The effect of Gymnema sylvestre and Camelia sinensis on patients with Type 2 diabetes mellitus. Health Environ J 2016;7(2):1-19.

67. Kasabri V, Fatma UA, Yasser B, Sundus M, Randa N, Hala SM. In vitro enhancement of pancreatic $\beta$ cells MIN6 proliferation by 
insulinotropic Gymnema sylvestre aqueous extracts: Evidence-based regenerative therapeutic capacity of a medicinal herb. Br J Med Med Res 2015;7(3):180-94.

68. Thanwar M, Dwivedi D, Gharia AK, Chouhan S. Antibacterial study of Gymnema sylvestre plant. Int J Chem Stud 2016;4(3):80-3.

69. Satdive RK, Abhilash P, Fulzele DP. Antimicrobial activity of Gymnema sylvestre Leaf extract. Fitoterapia 2003;74(7-8):699-701.

70. Wani M, Sarvar FA, Agrawal J, Deshpande J, Mathew S, Khetmalas M. Qualitative phytochemical analysis and antimicrobial activity studies of Gymnema sylvestre R. Br. Acta Biol Indica 2012;1(1):121-4.

71. David BC, Sudarsanam G. Antimicrobial activity of Gymnema sylvestre (Asclepiadaceae). J Acute Dis 2013;2(3):222-5.

72. Kaushik M, Kaushik A, Arya R, Singh G, Malik P. Antiobesity property of hexane extract from leaves of Gymnema sylvestre in high fed cafeteria diet induced obesity rat. Int Res J Pharm 2011;2(8):112-6.

73. Luo H, Kashiwagi A, Shibahara T, Yamada K. Decreased bodyweight without rebound and regulated lipoprotein metabolism by gymnemate in genetic multifactor syndrome animal. Mol Cell Biochem 2007;299(1-2):93-8.

74. Woodgate DE, Conquer JA. Effects of a stimulant-free dietary supplement on body weight and fat loss in obese adults: A six-week exploratory study. Currt Ther Res 2003;64(4):248-62.

75. Norihiro S, Asano R, Shimosaka M, Okazaki M. Effect of administration with the extract of Gymnema sylvestre $\mathrm{R}$. Br leaves on lipid metabolism in Rats. Biol Pharm Bull 2001;24(6):713-7.

76. Preuss HG, Jarrell ST, Scheckenbach R, Lieberman S, Anderson RA. Comparative effects of chromium, vanadium and Gymnema sylvestre on sugar-induced blood pressure elevations in SHR. J Am Coll Nutr 1998;17(2):116-23.

77. Nakamura Y, Tsumura Y, Tonogai Y, Shibata T. Fecal steroid excretion is increased in rats by oral administration of gymnemic acids contained in Gymnema sylvestre Leaves. J Nutr 1999;129:1214-22.

78. Mall GK, Mishra PK, Prakash V. Antidiabetic and hypolipidemic activity of Gymnema sylvestre in alloxan induced diabetic rats. Glob J Biotechnol Biochem 2009;4(1):37-42.

79. Reddy JN, Mata R, Bhagat E, Sadras SR. Green synthesis of silver and gold nanoparticles from Gymnema sylvestre leaf extract: Study of antioxidant and anticancer activities. J Nanopart Res 2015;17:151.

80. Khanna VG, Kannabiran K. Anticancer-cytotoxic activity of saponins isolated from the leaves of Gymnema sylvestre and Eclipta prostrata on HeLa cells. Int J Green Pharm 2009;???:227-9.

81. Agrawal RC, Soni S, Jain N, Rajpoot J, Maheshwari SK. Chemopreventive effect of Gymnema sylvestre in Swiss albino mice. Int J Sci Res Publ 2016;3(1):78-83.

82. Singh K, Deo B. Phytochemical evaluation and in vitro antioxidant activity of Gymnema sylvestre R.Br. J Med Plants Stud 2014;2(4):19-23.

83. Kaskoos RA, Hagop AB, Faraj AM, Ahamad J. Comparative antioxidant activity of Gymnema sylvestre, Enicostemma littoral, Momordica charantia and their composite extract. J Pharmacogn Phytochem 2015;4(1):95-8.

84. Ahirwal L, Singh S, Dubey MK, Bharti V, Mehta A, Shukla S. In vivo immunomodulatory effects of the methanolic leaf extract of Gymnema sylvestre in Swiss albino mice. Arch Biol Sci Belgrade 2015;67(2):561-70.

85. Malik JK, Manvi FV, Nanjware BR. Wound healing properties of alcoholic extract of Gymnema sylvestre R.Br. Leaves in rats. J Pharm Res 2009;2:1029-30.

86. Aleisa AM, Al-Rejaie SS, Abuohashish HM, Ola MS, Parmar MY, Ahmed MM. Pretreatment of Gymnema sylvestre revealed the protective against acetic acid-induced ulcerative colitis in rats. BMC Complement Altern Med 2014;14:49.

87. Lilly BA, Aarrthy MA, Kantha DA, Annamalai SK, Kalaivani AK. In vivo anti-ulcer, anti-stress, anti-allergic, and functional properties of gymnemic acid isolated from Gymnema sylvestre $\mathrm{R} \mathrm{Br}$. BMC Complement Altern Med 2014;14(1):70.

88. Nasreen S, Radha R. Assessment of quality of Withania somnifera Dunal (Solanaceae) pharmacognostical and phyto-physicochemical profile. Int J Pharm Pharm Sci 2011;3:152-5.

89. Babu M, Gnanamani A, Radhakrishan N, Priya K. Healing potential of Datura alba on burn wounds in Albino rats. J Ethnopharmacol 2002;83:193-9. 